\title{
Synthesis of 1'-Epi-stegobinone
}

\author{
Takashi EBATA and Kenji Mori* \\ Life Science Research Laboratory, Japan Tobacco Inc, 6-2, Umegaoka, \\ Midori-ku, Yokohama 227, Japan \\ * Department of Agricultural Chemistry, The University of Tokyo, \\ 1-1-1, Yayoi, Bunkyo-ku, Tokyo 113, Japan \\ Received September 28, 1989
}

\begin{abstract}
1'-Epi-stegobinone [(2S,3R,1'S)-2,3-dihydro-2,3,5-trimethyl-6-(1'-methyl-2'-oxobutyl)-4Hpyran-4-one], an inhibitor of stegobinone, which is the sex pheromone of drugstore beetle (Stegobium paniceum L.), was synthesized by stereocontrol at C-2 and C-1' starting from ethyl (R)-3-hydroxybutanoate and methyl $(R)$-3-hydroxypentanoate.
\end{abstract}

The drugstore beetle (Stegobium paniceum L.) is known as a devastating pest of stored food and crops. The sex pheromone of this insect, stegobinone (1) was isolated by Kuwahara et al., ${ }^{1)}$ and very recently, stegobiol (2) has been isolated by Kodama et $a l^{2)}$ Previously, we reported the synthesis of both the pheromones in a stereoselective manner and confirmed the absolute stereochemistry of the natural pheromone to be $\left(2 S, 3 R, 1^{\prime} R\right)-1^{3)}$ and $\left(2 S, 3 R, 1^{\prime} S, 2^{\prime} S\right)-2{ }^{4)}$ respectively. Our chemical studies on the sex pheromone of drugstore beetle revealed the biologically interesting fact that $\left(2 S, 3 R, 1^{\prime} R S\right)-1$ had no pheromone activity against the drugstore beetle in contrast with $\left(2 S, 3 R, 1^{\prime} R\right)-1 .^{3)}$ This fact suggested that $\left(2 S, 3 R, 1^{\prime} S\right)-3$ inhibited the pheromone activity of $\left(2 S, 3 R, 1^{\prime} R\right)-1$ (stegobinone). Very recently, Kodama et al. also reported the inhibition of the male response of drugstore beetle against racemic stegobinone (1) by its racemic 1'-epimer (3). ${ }^{5)}$ It is very rare case that one of the diastereomers, and not an enantiomer, inhibits an other's pheromone activity. Only one example has been reported about this type of inhibition to data. $\left.{ }^{6}\right)$ Moreover, very recently Kodama's investigation suggested another interesting fact. That is, $\left(2 S, 3 R, 1^{\prime} R, 2^{\prime} R\right)-4$ inhibited the activity of $\left(2 S, 3 R, 1^{\prime} S, 2^{\prime} S\right)-2$ (stegobiol). ${ }^{7)}$ In order to clarify the stereochemistry-inhibitory activity relationship, we became interested in synthesizing these two compounds in an optically pure state.

As shown in Fig. 1, our synthetic strategy for $\mathbf{3}$ and $\mathbf{4}$ was the same as that employed previously for stegobinone (1) ${ }^{3)}$ and stegobiol (2). ${ }^{4)}$ An intramolecular acylation $(\mathbf{1 0} \rightarrow \mathbf{3})$ was the key-step, the starting materials being ethyl $(R)$-3-hydroxybutanoate $(5)^{8)}$ and methyl $(R)$ 3-hydroxypentanoate (7). These esters were readily available in quantity by microbial processes and were employed by us for natural product synthesis. ${ }^{3,4,10}$ )

The 13-step conversion of $\mathbf{5}$ to hydroxy ketone 6 was carried out as reported previously by us in a $27.0 \%$ overall yield. ${ }^{3)}$ The chemical purity of 6 was shown to be $>97 \%$ with an optical purity of $100 \%$. Another key intermediate (9) was derived from 7 via $8 \mathbf{a}$. The 3-step conversion of $\mathbf{7}$ to $\mathbf{8 a}$ was carried out as reported previously in a $12.3 \%$ overall yield. ${ }^{11}$ Both the chemical and optical purities of $\mathbf{8 a}$ were shown to be $100 \%$. Silylation of $8 \mathrm{a}$ with $t$ butyldimethylsilyl chloride (TBDMS $\mathrm{Cl}$ ) gave $\mathbf{8 b}$ in a $90.0 \%$ yield. This ester $\mathbf{8 b}$ was saponified with $\mathrm{KOH}$ aq. to give 9 in a $95.2 \%$ yield. Esterification of 9 with 6 was carried out under Yamaguchi conditions, ${ }^{12}$ ) but using commercially available 2,6-dichlorobenzoyl chloride instead of the 2,4,6-trichlorobenzoyl chloride of the original procedure,,$^{3,4,10 b}$ to 

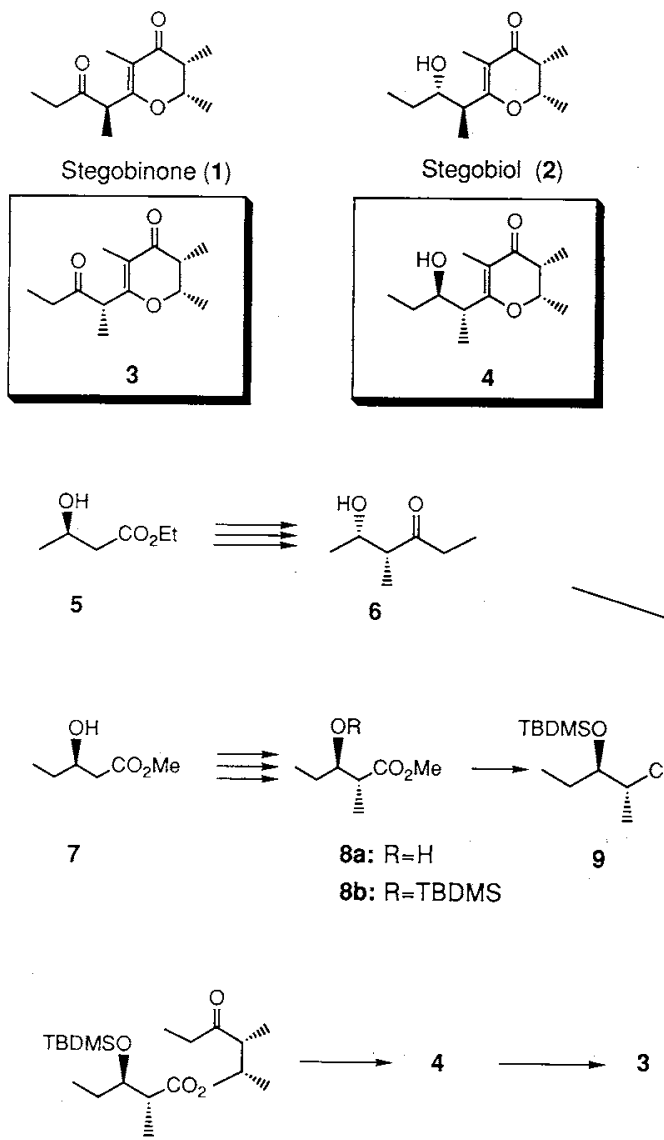

Fig. 1. Structures of the Target Molecules and Their Syntheses. give $\mathbf{1 0}$ in an $89.7 \%$ yield. Treatment of $\mathbf{1 0}$ with 2 eq. of lithium hexamethyldisilazide, which was followed by acidification with monochloroacetic acid and deprotection with hydrogen fluoride, afforded $4,[\alpha]_{\mathrm{D}}^{23}-100^{\circ}$ $\left(\mathrm{CHCl}_{3}\right)$, in a $13.8 \%$ yield after purification by preparative TLC. The IR, NMR and mass spectral properties supported the structure of 4. Subsequent oxidation of $\mathbf{4}$ under Swern conditions gave 3 as crystals ( $\mathrm{mp} 47-48^{\circ} \mathrm{C}$; in lit., $\left.{ }^{13)} \mathrm{mp} 4648^{\circ} \mathrm{C}\right),[\alpha]_{\mathrm{D}}^{23}+8.1^{\circ}\left(\mathrm{CHCl}_{3}\right)$ in a $63.0 \%$ yield after purification by preparative TLC. The stereochemical homogeneity at C-1' of our synthetic 3 was confirmed to be $>99 \%$ by $500 \mathrm{MHz}{ }^{1} \mathrm{H}-\mathrm{NMR}$ measurement and also by HPLC analysis.

The CD spectral data of stegobiol (2) and its $\left(2 S, 3 R, 1^{\prime} R, 2^{\prime} R\right)$-isomer (4) are listed in Table $I$, and those of stegobinone (1) and $1^{\prime}$-epi-
Table I. CD Spectral Data of 2 AND 4

\begin{tabular}{ccccc}
\hline & 2 & & \multicolumn{2}{c}{4} \\
\cline { 4 - 5 }$\lambda(\mathrm{nm})$ & $\Delta \varepsilon$ & & $\lambda(\mathrm{nm})$ & $\Delta \varepsilon$ \\
\hline 355 & -0.80 & & 355 & -0.46 \\
341 & -1.64 & & 340 & -0.98 \\
329 & -1.69 & & 329 & -1.20 \\
282 & +0.25 & 285 & -0.08 \\
254 & -0.82 & 255 & -0.94 \\
\hline
\end{tabular}

stegobinone (3) in Table II. As can be seen from Table I, compounds 2 and 4 showed almost the same CD spectral properties. On the other hand, the CD spectral data of 1 and 3 had very significant differences in the 250 to $300 \mathrm{~nm}$ region. It was apparent that these differences were caused by the perturbation of the $\mathrm{C}-2^{\prime}$ carbonyl group. 
Table II. CD SPECTRAL Data of 1 AND 3

\begin{tabular}{cccccc}
\hline \multicolumn{2}{c}{1} & & & \multicolumn{2}{c}{3} \\
\cline { 1 - 2 } \cline { 5 - 5 } & $\Delta \varepsilon$ & & $\lambda(\mathrm{nm})$ & $\Delta \varepsilon$ \\
\hline 360 & -0.46 & & 360 & -0.88 \\
345 & -0.86 & & 345 & -2.18 \\
332 & -0.69 & & 331 & -2.34 \\
290 & -12.9 & & 285 & +13.4 \\
262 & +8.8 & 261 & -10.9 \\
\hline
\end{tabular}

In conclusion, 1'-epi-stegobinone (3) was synthesized via $\left(2 S, 3 R, 1^{\prime} R, 2^{\prime} R\right)$-stegobiol (4). The overall yield was $2.1 \%$ in 18 steps from $\mathbf{5}$, or $0.8 \%$ in 10 steps from 7 . Biological studies on our synthetic $\mathbf{3}$ and $\mathbf{4}$ are now underway.

\section{Experimental}

All bp and $m p$ data are uncorrected. IR spectra were measured as films on a JASCO A-102 spectrometer. ${ }^{1} \mathrm{H}$ NMR spectra were recorded at $60 \mathrm{MHz}$ with TMS as an internal standard on a Hitachi R-24A spectrometer, unless otherwise stated. Optical rotations were measured on a JASCO DIP-140 polarimeter, mass spectra were recorded at $70 \mathrm{eV}$ on a JEOL DX-300 spectrometer. CD spectra were recorded on a JASCO J-20 automatic spectropolarimeter.

Methyl (2R,3R)-3-t-butyldimethylsilyloxy-2-methylpentanoate $(\mathbf{8 b})$. Imidazole $(300 \mathrm{mg}, 4.41 \mathrm{mmol}$ ) and TBDMS C1 $(443 \mathrm{mg}, 2.94 \mathrm{mmol}$ ) were added to a stirred solution of $8 \mathrm{a}(326 \mathrm{mg}, 2.23 \mathrm{mmol})$ in dry DMF $(5 \mathrm{ml})$. The mixture was stirred overnight at room temp., before being poured into an ice-water mixture and extracted with ether. The ether solution was washed with water and brine, dried $\left(\mathrm{MgSO}_{4}\right)$ and concentrated in vacuo. The residue was distilled to give $522 \mathrm{mg}(90.0 \%)$ of $\mathbf{8 b}$, bp $87-88^{\circ} \mathrm{C}$ $(5 \mathrm{mmHg}) ; n_{\mathrm{D}}^{23} 1.4278 ;[\alpha]_{\mathrm{D}}^{23}-38.0^{\circ}\left(c=0.79, \mathrm{CHCl}_{3}\right) ; \mathrm{IR}$ $v_{\max } \mathrm{cm}^{-1} 2980(\mathrm{~m}), 2960(\mathrm{~m}), 2910(\mathrm{~m}), 2880(\mathrm{~m}), 1745(\mathrm{~s})$, $1465(\mathrm{~m}), 1260(\mathrm{~m}), 1120(\mathrm{~m}), 840(\mathrm{~s}) ; \mathrm{NMR} \delta\left(\mathrm{CCl}_{4}\right) 0.04$ $(6 \mathrm{H}, \mathrm{s}), 0.81(3 \mathrm{H}, \mathrm{t}, J=7 \mathrm{~Hz}), 0.84(9 \mathrm{H}, \mathrm{s}), 1.02(3 \mathrm{H}, \mathrm{d}, J=$ $7 \mathrm{~Hz}), 1.09-1.70(2 \mathrm{H}, \mathrm{m}), 2.51(1 \mathrm{H}, \mathrm{dq}, J=7$ and $7 \mathrm{~Hz})$, $3.54(3 \mathrm{H}, \mathrm{s}), 3.6-4.0(1 \mathrm{H}, \mathrm{m})$. Anal. Found: C, $59.63 ; \mathrm{H}$, 10.64. Caled. for $\mathrm{C}_{13} \mathrm{H}_{28} \mathrm{O}_{3}$ Si: C, $59.95 ; \mathrm{H}, 10.84 \%$.

$(2 R, 3 R)-3-t$-Butyldimethylsilyloxy-2-methylpentanoic acid (9). To a stirred solution of $8 \mathrm{~b}(502 \mathrm{mg}, 1.93 \mathrm{mmol})$ in $\mathrm{MeOH}(6 \mathrm{ml})$ was added dropwise $1 \mathrm{~N} \mathrm{KOH}$ aq. $(3 \mathrm{ml}$, $3 \mathrm{mmol})$. The mixture was stirred for $6 \mathrm{hr}$ under reflux, and after cooling, was concentrated in vacuo to remove $\mathrm{MeOH}$. The residue was extracted with ether, and the aq. layer was acidified ( $\mathrm{pH} 5$ ) by the addition of $\mathrm{AcOH}$. This was then extracted with ether. The ether solution was washed with water, dried $\left(\mathrm{MgSO}_{4}\right)$ and concentrated in vacuo to give $452 \mathrm{mg}(95.2 \%)$ of 9 , IR $v_{\max } \mathrm{cm}^{-1} 3000(\mathrm{br}$ ), $2960(\mathrm{~s})$, $2940(\mathrm{~s}), 2900(\mathrm{~m}), 2860(\mathrm{~m}), 1720(\mathrm{~s}), 1460(\mathrm{~m}), 835(\mathrm{~s})$, 775 (s). This was employed in the next step without further purification.

( $\left.I^{\prime} S, 2^{\prime} S\right)-I^{\prime}, 2^{\prime}$-Dimethyl-3-oxopentyl $(2 R, 3 R)$-3-t-butyldimethylsilyloxy-2-methylpentanoate (10). 2,6-Dichlorobenzoyl chloride $(852 \mathrm{mg}, 4.07 \mathrm{mmol})$ was added to a mixture of $9(1.00 \mathrm{~g}, 4.07 \mathrm{mmol})$ and $\mathrm{Et}_{3} \mathrm{~N}(452 \mathrm{mg}, 4.48$ $\mathrm{mmol})$ in dry THF $(20 \mathrm{ml})$ under Ar. The mixture was stirred overnight at room temp. After the removal of $\mathrm{Et}_{3} \mathrm{~N}-\mathrm{HCl}$ by filtration, the filtrate was concentrated under $\mathrm{N}_{2}$, and the residue was dissolved in dry $\mathrm{C}_{6} \mathrm{H}_{6}$ $(15 \mathrm{ml})$. To this solution were added a solution of 6 $(529 \mathrm{mg}, 4.07 \mathrm{mmol})$ in dry $\mathrm{C}_{6} \mathrm{H}_{6}(5 \mathrm{ml})$ and DMAP $(546 \mathrm{mg}, 4.48 \mathrm{mmol})$ in dry $\mathrm{C}_{6} \mathrm{H}_{6}(15 \mathrm{mmol})$ at $0^{\circ}$ under Ar. The resulting mixture was stirred for $5 \mathrm{hr}$ at $0^{\circ} \mathrm{C}$. It was then diluted with ether $(20 \mathrm{ml})$, successively washed with $1 \mathrm{~N} \mathrm{HCl}$, water, saturated $\mathrm{NaHCO}_{3}$ aq. and brine, dried $\left(\mathrm{MgSO}_{4}\right)$ and concentrated in vacuo. The residue was purified by chromatography over $\mathrm{SiO}_{2}$ (Kieselgel $60,25 \mathrm{~g}$ ). Elution with $n$-hexane-ether $(20: 1)$ gave $1.31 \mathrm{~g}(89.7 \%)$ of 10, IR $v_{\max } \mathrm{cm}^{-1} 2980(\mathrm{~s}), 2950(\mathrm{~s}), 2900(\mathrm{~m}), 2870(\mathrm{~m})$, $1735(\mathrm{~s}), 1720(\mathrm{~s}), 1265(\mathrm{~s}), 1175(\mathrm{~s}), 1120(\mathrm{~s}), 1080(\mathrm{~s}), 1050$ (s), $1015(\mathrm{~s}), 835(\mathrm{~s}), 775(\mathrm{~s}) ; \mathrm{NMR} \delta\left(\mathrm{CCl}_{4}\right) 0.03(6 \mathrm{H}, \mathrm{s})$, $0.6-1.7(26 \mathrm{H}, \mathrm{m}$, containing $0.87,9 \mathrm{H}, \mathrm{s}), 2.2-2.9(2 \mathrm{H}, \mathrm{m})$, $3.65-4.0(1 \mathrm{H}, \mathrm{m}), 4.8-5.3(1 \mathrm{H}, \mathrm{m})$.

$\left(2 S, 3 R, 1^{\prime} R, 2^{\prime} R\right)$-Stegobiol (4). To a solution of $\mathbf{1 0}$ $(300 \mathrm{mg}, 0.84 \mathrm{mmol})$ in dry THF $(15 \mathrm{ml})$ and TMEDA $(13 \mathrm{ml})$ was slowly added dropwise a solution of lithium hexamethyldisilazide in dry THF $(0.34 \mathrm{M}, 2.47 \mathrm{ml}$, $0.84 \mathrm{mmol}$ ) with stirring at $-70^{\circ} \mathrm{C}$ under $\mathrm{Ar}$. The reaction temp. was gradually raised to $0^{\circ} \mathrm{C}$ over $2 \mathrm{hr}$. Then, the reaction mixture was cooled $\left(-70^{\circ} \mathrm{C}\right)$ again, and to it was added dropwise a solution of lithium hexamethyldisilazide in dry THF $(0.34 \mathrm{M}, 2.47 \mathrm{ml}, 0.84 \mathrm{mmol})$. The reaction temp. was gradually raised again to $0^{\circ} \mathrm{C}$ over $2 \mathrm{hr}$, before the mixture was poured into $10 \% \mathrm{ClCH}_{2} \mathrm{CO}_{2} \mathrm{H}$ aq $(80 \mathrm{ml})$ and THF $(80 \mathrm{ml})$. After stirring overnight at room temp, the solution was concentrated in vacuo to remove the THF. The residue was extracted with ether. The ether solution was successively washed with water, saturated $\mathrm{NaHCO}_{3}$ aq. and brine, dried $\left(\mathrm{MgSO}_{4}\right)$ and concentrated in vacuo. The residue was dissolved in $\mathrm{MeCN}(5 \mathrm{ml})$, to this solution were added 7 drops of $46 \% \mathrm{HF}$ aq. After stirring for $5 \mathrm{hr}$ at room temp., the mixture was diluted with ether $(20 \mathrm{ml})$. The ether solution was washed with water, dried $\left(\mathrm{MgSO}_{4}\right)$ and concentrated in vacuo. The residue was purified by preparative TLC (Merck Kieselgel $60 \mathrm{~F}_{254}, n$ hexane-ether $=1: 3, R f=0.23)$ to give $26 \mathrm{mg}(13.8 \%)$ of $\mathbf{4}$, $[\alpha]_{\mathrm{D}}^{23}-80.0^{\circ}\left(c=0.1, \mathrm{CHCl}_{3}\right) ;$ IR $v_{\max } \mathrm{cm}^{-1} 3420(\mathrm{br}$.$) ,$ $2990(\mathrm{~m}), 2940(\mathrm{~m}), 2890(\mathrm{~m}), 1650(\mathrm{~s}), 1600(\mathrm{~s}), 1455(\mathrm{~m})$, $1380(\mathrm{~s}), 1345(\mathrm{~m}), 1215(\mathrm{~m}), 1145(\mathrm{~s}), 1115(\mathrm{~s}), 975(\mathrm{~m}) ;$ NMR $\delta\left(\mathrm{CDCl}_{3}, 500 \mathrm{MHz}\right) 1.00(3 \mathrm{H}, \mathrm{t}, J=7.4 \mathrm{~Hz}), 1.07$ 
$(3 \mathrm{H}, \mathrm{d}, J=7.3 \mathrm{~Hz}), 1.17(\mathrm{H}, \mathrm{d}, J=7.1 \mathrm{~Hz}), 1.35(3 \mathrm{H}, \mathrm{d}, J=$ $6.6 \mathrm{~Hz}), 1.4-1.5(1 \mathrm{H}, \mathrm{m}), 1.5-1.6(1 \mathrm{H}, \mathrm{m}), 1.75(3 \mathrm{H}, \mathrm{s}), 1.92$ $(1 \mathrm{H}, \mathrm{d}, J=7 \mathrm{~Hz}), 2.32(1 \mathrm{H}, \mathrm{dq}, J=3.2$ and $7.3 \mathrm{~Hz}), 2.84$ $(1 \mathrm{H}, \mathrm{dq}, J=7.1$ and $7.1 \mathrm{~Hz}), 3.54-3.63(1 \mathrm{H}, \mathrm{m}), 4.43$ ( $1 \mathrm{H}, \mathrm{dq}, J=3.2$ and $6.6 \mathrm{~Hz}) . \mathrm{CD}(\Delta \varepsilon$ in $n$-hexane) -0.94 $(255 \mathrm{~nm}), \quad-0.08(285 \mathrm{~nm}), \quad-1.20 \quad(329 \mathrm{~nm}), \quad-0.98$ $(340 \mathrm{~nm}),-0.46(355 \mathrm{~nm})$. MS $(\mathrm{m} / \mathrm{z}) 227\left(\mathrm{M}^{+}+1,5 \%\right)$, $226\left(\mathrm{M}^{+}, 30 \%\right), 168(72 \%), 124(22 \%), 113(80 \%), 112$ $(100 \%), 109(21 \%), 83(61 \%), 59(30 \%), 57(27 \%), 56$ $(23 \%), 55(30 \%)$. Found: MS $(\mathrm{m} / \mathrm{z}) 226.1559\left(\mathrm{M}^{+}\right)$. Calcd. for $\mathrm{C}_{13} \mathrm{H}_{22} \mathrm{O}_{3}: 226.1569$.

$\left(2 S, 3 R, I^{\prime} S\right)$-Stegobinone (3). To a cooled $\left(-70^{\circ} \mathrm{C}\right)$ and stirred solution of oxalyl chloride $(39.4 \mathrm{mg}, 0.31 \mathrm{mmol})$ in $\mathrm{CH}_{2} \mathrm{Cl}_{2}(3 \mathrm{ml})$ was added dropwise a solution of DMSO (32.3 $\mathrm{mg}, 0.41 \mathrm{mmol})$ in dry $\mathrm{CH}_{2} \mathrm{Cl}_{2}(0.6 \mathrm{ml})$ under Ar. The mixture was stirred for $2 \mathrm{~min}$ at $-70^{\circ} \mathrm{C}$, and then a solution of $4(46.8 \mathrm{mg}, 0.21 \mathrm{mmol})$ in dry $\mathrm{CH}_{2} \mathrm{Cl}_{2}(0.6 \mathrm{ml})$ was added dropwise with stirring. After $50 \mathrm{~min}$ at $-70^{\circ} \mathrm{C}$, $\mathrm{Et}_{3} \mathrm{~N}$ (105 mg, $1.04 \mathrm{mmol}$ ) was added dropwise, and the stirring was continued for $15 \mathrm{~min}$ at this temp. The mixture was allowed to warm to $0^{\circ} \mathrm{C}$, stirred for $20 \mathrm{~min}$ at this temp., and partitioned between a mixture of $\mathrm{C}_{6} \mathrm{H}_{6}$-ether $(4: 1,6 \mathrm{ml})$ and water $(6 \mathrm{ml})$. The organic layer was washed with brine, dried $\left(\mathrm{MgSO}_{4}\right)$ and concentrated in vacuo. The residue was purified by preparative TLC (Merck, Kieselgel $60 \mathrm{~F}_{254}, n$-hexane-ether $\left.=1: 1, R f=0.42\right)$ to give $29.2 \mathrm{mg}$ $(63 \%)$ of $3, \mathrm{mp} 47-48^{\circ} \mathrm{C},[\alpha]_{\mathrm{D}}^{23}+8.1^{\circ}\left(\mathrm{c}=0.11, \mathrm{CHCl}_{3}\right)$; IR $v_{\max } \mathrm{cm}^{-1} 2995(\mathrm{~s}), 2950(\mathrm{~s}), 2890(\mathrm{~m}), 1725(\mathrm{~s}), 1665(\mathrm{~s})$, $1610(\mathrm{~s}), 1455(\mathrm{~s}), 1385(\mathrm{~s}), 1345(\mathrm{~s}), 1215(\mathrm{~s}), 1145(\mathrm{~s}), 1120$ (s), $1095(\mathrm{~m}), 1050(\mathrm{~s}), 955(\mathrm{~m}), 915(\mathrm{~m}), 705(\mathrm{~m})$; NMR $\delta$ $\left(\mathrm{CDCl}_{3}, 500 \mathrm{MHz}\right), 1.05(3 \mathrm{H}, \mathrm{d}, J=7.3 \mathrm{~Hz}), 1.07(3 \mathrm{H}$, $\mathrm{t}, J=7.3 \mathrm{~Hz}), 1.29(3 \mathrm{H}, \mathrm{d}, J=7.1 \mathrm{~Hz}), 1.30(3 \mathrm{H}, \mathrm{d}$, $J=6.7 \mathrm{~Hz}), 1.80(3 \mathrm{H}, \mathrm{s}), 2.31-2.56(3 \mathrm{H}, \mathrm{m}), 3.65(1 \mathrm{H}, \mathrm{q}$, $J=7.1 \mathrm{~Hz}), 4.43(1 \mathrm{H}, \mathrm{dq}, J=3.4$ and $6.7 \mathrm{~Hz})$ CD $(\Delta \varepsilon$ in $n$-hexane $)-10.9(261 \mathrm{~nm}),+13.4(288 \mathrm{~nm}),-2.34$ $(331 \mathrm{~nm}),-2.18(345 \mathrm{~nm}),-0.88(360 \mathrm{~nm}) . M S(m / z) 224$ $\left(\mathrm{M}^{+}, 21 \%\right), 169(13 \%), 168(100 \%), 139(13 \%), 124(17 \%)$, $112(14 \%), 109(15 \%), 83(20 \%), 57(81 \%), 55(13 \%)$. HPLC (column, Nucleosil $50-5,25 \mathrm{~cm} \times 4.6 \mathrm{~mm}$; solvent,
$n$-hexane-THF-MeOH $=6000: 100: 2$; flow rate, $1.0 \mathrm{ml}$ / $\min )$ Rt $2.18 \mathrm{hr}(99.5 \%), 2.31 \mathrm{hr}(0.5 \%)$. Found: $\mathrm{MS}(\mathrm{m} / \mathrm{z})$ 224. $1450\left(\mathrm{M}^{+}\right)$. Calcd. for $\mathrm{C}_{13} \mathrm{H}_{20} \mathrm{O}_{3}: 224.1412$.

Acknowledgment. Our thanks are due to Drs. $\mathrm{H}$. Kodama, T. Chuman and H. Matsushita for their valuable suggestions to undertake the present work.

\section{References}

1) Y. Kuwahara, H. Fukami, R. Howard, S. Ishii, F. Matsumura and W. E. Burkholder, Tetrahedron, 34, 1769 (1978).

2) H. Kodama, M. Ono, M. Kohno and A. Ohnishi, $J$. Chem. Ecol., 13, 1871 (1987).

3) K. Mori and T. Ebata, Tetrahedron, 42, 4413 (1986)

4) K. Mori and T. Ebata, Tetrahedron, 42, 4685 (1986).

5) H. Kodama, K. Mochizuki, M. Kohno, A. Ohnishi and Y. Kuwahara, J. Chem. Ecol., 13, 1859 (1987).

6) M. Mori, K. Mochizuki, M. Kohno, T. Chuman, A. Ohnishi, H. Watanabe and K. Mori, J. Chem. Ecol., 12, 83 (1986).

7) Kodama's personal communication to T. E

8) T. Sugai, M. Fujita and K. Mori, Nippon Kagaku Kaishi (J. Chem. Soc. Jpn.), 1983, 1315.

9) J. Hasegawa, S. Hamaguchi, M. Ogura and K. Watanabe, J. Ferment. Technol., 59, 257 (1981).

10) a) K. Mori and T. Ebata, Tetrahedron, 42; 4421 (1986)

b) T. Ebata and K. Mori, Agric. Biol. Chem., 51, 2925 (1987).

11) M. Kato and K. Mori, Agric. Biol. Chem., 49, 3073 (1985).

12) J. Inanaga, K. Hirata, H. Saeki, T. Katsuki and M. Yamaguchi, Bull. Chem. Soc. Jpn., 52, 1989 (1979).

13) R. W. Hoffmann, W. Ladner, K. Steinbach, W. Massa, R. Schmidt and G. Snatzke, Chem. Ber., 114, 2786 (1981). 